To cite this article: Katrien Van Poeck, Joke Vandenabeele \& Hans Bruyninckx (2014)

Taking stock of the UN Decade of education for sustainable development: the policy-making process in Flanders, Environmental Education Research, 20:5, 695-717

To link to this article: http://dx.doi.org/10.1080/13504622.2013.836622

\title{
Taking stock of the UN Decade of Education for Sustainable Development: The policymaking process in Flanders
}

\begin{abstract}
In this paper we address the implementation of the UN-Decade of Education for Sustainable Development (ESD) in Flanders, a sub-national entity of Belgium. Our analysis shows how the policymaking process in Flanders is inextricably intertwined with three developments in environmental and educational policy: the increasing impact of ESD policy and discourse on environmental education, the framing of social and political problems as learning problems, and ecological modernisation. These trends give shape to a post-ecologist and post-political policy regime and, thus, affect what is possible and acceptable within Flemish ESD policy. However, this case study also revealed that these developments do not completely determine ESD policymaking in Flanders. Our examination thus allowed us to understand how the actual policy translation in a particular local setting brings about powers that legitimise and maintain as well as counteract the bounds of the policy regime that emerged in the context of the UN-Decade.
\end{abstract}

Keywords: education for sustainable development; ESD; UN Decade of ESD; policymaking; ecological modernisation; governmentalisation

The United Nations designated the period 2005-2014 as the Decade of Education for Sustainable Development (DESD). As this Decade comes to an end, the time has come to take stock of the actual policy translations and implementation processes it has brought about. In this paper, we aim to contribute to documenting the outcomes of the DESD with an empirical analysis of the policymaking process on education for sustainable development (ESD) in Flanders, a sub-national entity of the Belgian federal state. In academic literature, the concept of ESD and its desirability as a new leitmotiv for environmental education (EE) has been the subject of an extensive debate (see below). However, this lively discussion is characterised by a mainly 'non-empirical' approach 'dealing largely with theory or conceptual matters through literature review, discussion and/or commentary with no particular reference to the gathering or processing of empirical data' (Reid and Scott 2006: 582). Empirical studies analysing actual policy processes and outcomes (e.g. Nomura and Abe 2009; Huckle 2009) remain rare while political research on EE and ESD is vitally important so as to nourish this discussion by unsettling orthodoxies. Researchers, Ferreira (2009) argues, should therefore illustrate the battle between competing discourses and raise questions about taken-for-granted assumptions in ESD policymaking and about how these influence thoughts and practices in the field.

Hence, the aim of this article is to contribute to the empirical underpinning of the debate about EE and ESD with a case study of ESD policymaking in Flanders. In the next 
section, we analyse Flemish ESD policy so as to document the implementation of the DESD in this particular case. For this analysis, we have been inspired by the Policy Arrangements Approach (Arts et al. 2006), an analytical framework that seeks a balance between examining strategic actions of the actors involved in a policy process on the one hand and taking into account overall social and political changes on the other. Thus, we document Flemish ESD policymaking in terms of the actors involved, the resources that are mobilised, the rules of the game as well as the discourses regulating policy practice on ESD and, subsequently, we relate this day-to-day policymaking process to three broader social and political developments that have been extensively described in literature: the aforementioned growing influence of ESD policy and discourse on EE, the tendency to frame social and political problems as learning problems, and ecological modernisation. The literature on these developments incited us to be attentive for the implications of these tendencies that have been addressed by several authors. As we will argue, these developments contribute to a post-ecologist and post-political policy regime with regard to ESD which governs to a certain extent that which is (im-)possible to think and to do in ESD policy and practice. By bringing this forward, drawing on the insights and considerations emerging from our case study, we want to illuminate orthodoxies in EE and ESD but also show how, at particular moments, something else does become possible and raise questions about some taken-for-granted assumptions within this regime. Thus, we aim at contributing to a more critical and in depth understanding of the DESD and to inspire researchers in other contexts to undertake similar inquiries.

\section{ESD-policy in Flanders}

Flanders is a subnational entity of Belgium. The Belgian federal state (at the national level) consists of six subnational entities: three communities (the Flemish Community, the French Community and German-speaking Community) and three region (the Flemish Region, the Brussels-Capital Region and the Walloon Region). In Belgium, ESD is an authority distributed to the subnational level. This article focuses on the subnational entity of Flanders which consists of the Flemish Community and the Flemish Region. The Flemish authorities consist of the Flemish Parliament, the Government of Flanders, and the Flemish administration. The last is subdivided into 13 policy areas, each composed of a department (responsible for the preparation and evaluation of the policy and regulations) and several agencies (implementing the policy). Flanders is a densely populated region with 6300000 inhabitants $\left(466 / \mathrm{km}^{2}\right)$ (Flemish government 2012a). As to the available income, the region ranks among the top three of the best performing EU countries. The income of 10 per cent of the Flemings does not exceed the poverty line. In 2007, the Global Footprint Network (2013) determined the footprint of an average Belgian at 8 global hectares ${ }^{1}$ which is significantly higher than that of an average world citizen (2.7) and also of the average inhabitants of neighbouring countries France (5.0), Germany (5.1), The Netherlands (6.2) and the UK (4.9). Several 'sustainability indicators' monitored by the Flemish government reveal a 'critical situation', particularly those with regard to energy, climate change, transport, and biodiversity.

\footnotetext{
${ }^{1}$ The world average bio-capacity, that is the surface area of agricultural land, forest and fishing territory available, is 1.8 gha per capita.
} 
For this case study, we strived for triangulation of qualitative data sources (Patton 2002) and therefore gathered an empirical basis for our analysis by means of an in-depth interview, a postal survey, and an extensive document analysis. As interviewing all the relevant actors involved would have been unfeasible within the available time, we decided to interview a policy advisor responsible for the implementation of the DESD in Flanders who can be considered a key respondent with regard to Flemish ESD policymaking. It can reasonably be assumed that this policy advisor is the best qualified respondent so as to obtain up-to-date, first-hand information about the policymaking process and its output. We complemented the data derived from this interview by surveying the members of the 'ESD consultation platform' (see below). A postal survey with open questions has been answered by 15 respondents and the diversity of these respondents represents the variety of the actors involved. Furthermore, we analysed 23 international and 36 Flemish policy documents. We imported the verbatim transcription of the audio-recorded interview, the answers to the survey questionnaire as well as the policy documents into the qualitative analysis software QSR NVivo. 'Sensitising concepts' (Patton 2002, 278) - built upon both the dimensions we aim to describe (actors, resources, rules of the game, discourses / policy programmes) and the three developments we want to take into account - guided our analysis and were the first nodes used for coding. As the analysis advanced, these sensitising concepts were complemented, refined, adjusted, etc. according to insights arising from the data.

A point of particular interest, methodologically, is the fact that the researcher who conducted the analysis had formerly been a civil servant involved in the implementation of the DESD through facilitating networking within the ESD consultation platform as well as capacity building concerning ESD for EE practitioners. This position enabled an increased access to information as well as a thorough acquaintanceship with the field. On the other hand, it should be acknowledged that, because of this 'double role', involvement with the subject of research can be regarded above average. We took these considerations seriously and made every effort to carefully consider and control the balance between distance and involvement with the subject of our analysis. We started the data collection in the field (the interview and survey - see below) as well as data analysis only after the researcher had quit being a civil servant and worked for the university with a $\mathrm{PhD}$ scholarship. Furthermore, we emphasised this independent position in the communication with the people under study and assured them that all the data would be treated anonymously.

\section{The actors involved}

As we will show, ESD policy in Flanders is a two-track policy strongly guided by international institutions and developments but also embedded in the Flemish overall sustainable development policy. At the high-level meeting of Environment and Education Ministries in Vilnius in 2005, Flanders committed itself to the implementation of the Strategy for ESD developed by the United Nations Economic Commission for Europe (UNECE). This Strategy stressed the importance of shared responsibilities, cooperation, and participation of relevant stakeholders (UNECE 2005). UNESCO, designated by the UN General Assemblee as the leading agency of the DESD, also emphasised in its International Implementation Scheme the importance of alliances, partnerships between relevant actors within governments (sub- 
national, national, regional and international) as well as in civil society and the private sector (UNESCO 2005).

As the in-depth interview, postal survey, and policy documents show, this emphasis put on multi-level and multi-actor cooperation also characterised the Flemish ESD policymaking. The importance of cooperation and broad participation has repeatedly been underlined by all actors involved and was implemented by the establishment of an 'ESD consultation platform' (VLOR and Minaraad 2007; Verheyen 2009; Flemish government 2009a). This platform was created in response to UNECE's appeal to install a coordination mechanism for the ESD Strategy in order to stimulate implementation, information exchange, and partnerships. It was composed of representatives of diverse public administrations on different levels including ministers' political advisors, and non-state actors such as NGOs, unions, institutes for higher education, school systems within compulsory education and strategic advisory councils. The platform was given a mandate by the Government of Flanders to coordinate the implementation of the DESD, to contribute to its implementation by formulating advisory opinions as well as to foster multi-actor, multi-level, and multi-sector collaboration. In response to our survey, the actors involved described their contribution to ESD policymaking and the role they take in the platform on different domains. Public servants regularly mentioned their contribution to the preparation and implementation of ESD policy. Non-state actors often referred to the task of following up ESD policy, trying to influence it, representing their organisation or sector, and contributing to the implementation by applying ESD in concrete practices.

'I voice the stand of my organisation at the diverse consultative bodies. Within my organisation I transfer the information of the consultative bodies to those colleagues that coach the schools. Internally, I try to put ESD on the agenda of our coaching and training units. Up till now with limited results. Sometimes, I directly communicate with schools, e.g. so as to announce didactic tools, trainings.' (a staff member of a school system)

Seven respondents explicitly expressed appreciation of the consultation and cooperation within this platform. They particularly valued the opportunities it brought about for a dialogue on how the different partners involved understand ESD, which was experienced as an inducement to applying the concept in practices.

'ESD policy in Flanders enabled me to further develop my perception of ESD. The administration paid a lot of attention to consultation and that allowed me to compare my own view with that of others.' (a NGO staff member)

'The ESD consultation platform stimulated me and my organisation to take steps in translating ESD in our daily practices. Up till now, ESD is a very theoretical concept that is difficult to apply. Thanks to the exchange, we are able to further develop ESD in our own organisation as well as for other organisations.' (a NGO staff member)

The document analysis as well as the survey revealed repeated and sometimes severe criticism as to the assumed lack of commitment to ESD on the part of the Government. Several participants particularly questioned the lack of resources provided for the 
implementation of ESD. We will go into this matter later on. Furthermore, they expressed scepticism concerning the commitment of all relevant administrations such as the departments of Education, of Culture, and of Economy (e.g. Flemish government 2008a; Flemish government 2008b; Minaraad 2009). The interviewee explained that the Environment, Nature, and Energy Department - specifically the EE Unit - was the driving force behind the Flemish ESD policy through establishing, financing, and coordinating the ESD consultation platform and that, on the level of public administration, implementation always occurred in cooperation with the Department of Education and Training. The document analysis, interview, and the answers to our survey questionnaire also showed a persistent concern about other actors that were not or insufficiently involved in the Flemish ESD policy. Discussions in the ESD platform, advices by strategic advisory councils, and remarks of the respondents reflected discontent regarding the limited involvement of ESD practitioners and the overrepresentation of actors in the field of formal education and people with an environmental education background. There has been insisted on enhancing the engagement of actors in the field of non-formal learning and on bringing in more stakeholders from outside the EE sector. Particularly the involvement of partners from business circles and industrial sector umbrella organisations has been under discussion.

\footnotetext{
'Seeking alliances with the business world has been debated in the platform. Maybe we should reinforce the attempts to get those actors involved. Yet, we never reached agreement about that. It remained unclear how to succeed in it. Moreover, some people in the platform were all for it while others were rather sceptical.' (a civil servant)
}

In the course of the policy process, there has been an evolution in the participation of stakeholders. The interviewee explained that new actors, for instance from the field of higher education and the cultural sector, got involved appealed by concrete initiatives while others, such as the department of Economics, Science, and Innovation as well as ministers' political advisors quit participation. The policy advisor assumed that ESD has never been more than a side issue for them and got more and more pushed into the background as they found that the initiatives taken by the platform did not fit within their overall assignment. All the same, he explained, the bonds between maintaining participants were strengthened: stable relationships of trust have arisen, actors 'genuinely committed' to ESD were distinguished, and the people involved learned to know each other better so that it became clear whose expertise can be applied for what ends, which collaborations are possible for which objectives, etc. The evolving participation of the actors involved in the platform went together with a more or less conscious strategy of the EE Unit to move beyond the formal procedures and channels in their attempts to implement the ESD policy objectives in Flanders as those formal structures have proven to be difficult, inert, and resistant (see also below).

'The rather formal endeavour to implement ESD through official channels has been abandoned early on. We chose to invest in those opportunities where we saw that people were committed to ESD and willing to contribute to its implementation instead of continuing to try to embed ESD in formal structures where it might have had little opportunities.' (a civil servant) 
As such, in the course of time, a coalition arose of diverse actors trying to enhance and accelerate ESD policy and practices in Flanders. This coalition, gathered in the ESD consultation platform, strived for political validation of the ESD implementation plan (see below) as well as for providing the resources required to realise this plan. On the occasion of the election of the Flemish Parliament in 2009, for example, the president of the platform sent a memorandum to the relevant political actors in order to bring to their attention these concerns of the ESD consultation platform (Verheyen 2009). Members of the Strategic Advisory Council for Environment, Nature and Energy Policy who were also involved in the ESD consultation platform strengthened this coalition by writing advices for the Flemish Government and ministers that reflected concerns, opinions, and proposals introduced in the consultation platform (Minaraad 2007; Minaraad 2008; Minaraad 2009).

\section{The rules of the game}

In our description of the rules of the game influencing ESD policymaking in Flanders, it is important to distinguish between formal rules, laid down in laws and documents, and informal or de facto rules connected with certain policy cultures. Furthermore, rules can be formulated very rigorously as well as more broadly and they vary strongly concerning their degree of formality and compelling nature (Arts et al. 2000). ESD policy in Flanders was influenced by a number of rules of the game that were formally established though characterised by a low degree of authority. There was no imperative law forcing the Flemish Government or the other actors involved to implement ESD policy goals. Nevertheless, there were a few declarations and agreements with a powerful moral authority that influenced ESD policy and practice in Flanders.

At the international level, the roots of ESD policymaking were shaped by the Rio Declaration and Agenda 21 (1992) that considered learning to be indispensable for reaching sustainable development. The importance of ESD was later confirmed by the Johannesburg Plan of Implementation (2002), bringing about the installation of the DESD through resolution 57/254 of the United Nations General Assembly. Resolutions 58/219 and 59/237 offered additional support for the Decade. UNESCO's International Implementation Scheme (2005) and the UNECE Strategy for ESD (2005) made these appeals more concrete. In Flanders, the foundations of overall sustainable development policy are captured in the Belgian constitution in which sustainable development was included in 2007.

'During the exercise of their respective competences the federal state, the communities and the regions will pursue the goals of a sustainable development in its social, economic and environmental aspects, taking into account the solidarity between generations.' (Belgian Constitution, art. 7bis, 2007)

This affected Flemish policymaking: the application of the basic principles of sustainable development is now a constitutional obligation for the Government of Flanders. As a result, this Government adopted a regional decree on sustainable development in 2008 by means of which sustainable development obtained structural legal grounds. The decree aimed at ensuring the continuation of the Flemish sustainable development policy by obliging 
every newly formed Government to develop and adopt a 'Flemish Strategy for Sustainable Development'. As neither in the constitution, nor in the decree on sustainable development ESD is mentioned, there is no statutory obligation for an ESD policy in Flanders.

Nevertheless, in both the first (Leterme 2006) and the second (Peeters 2010) Flemish Strategy for Sustainable Development ESD has been given a prominent place. The policy goals were formulated formalistic rather than addressing specific content with regard to ESD, e.g. organising an ESD consultation platform, providing process coaching, integrating ESD in policy-, planning- and regulatory frameworks, installing an ESD coordination unit encompassing diverse policy areas, promoting ESD with financial policy instruments, stimulating ESD in formal education through final objectives and competence profiles, installing learning networks, etc. In 2009, the Government adopted the Flemish Implementation Plan concerning ESD 'Learning for a viable future' (Flemish government 2009a). The Plan was developed on a participatory basis via the ESD consultation platform and aimed at associating the UNECE Strategy for ESD with the specific Flemish context and the actions put forward in it were the same as these in the ESD-project of the first Flemish Strategy for Sustainable Development.

Several Flemish ministers stated in their policy documents for the term 2009-2014 that they intended to realise the ESD Implementation Plan (Peeters 2009a; 2009b; Schauvliege 2009; Smet 2009). Yet, numerous respondents were very critical and concluded that the political commitment to ESD is largely limited to paying lip service to the objectives formulated in the plan since those objectives were insufficiently translated in tangible measures or the provision of the necessary resources (see also below).

'ESD policy is extensively developed on paper. Yet, the realisation in real terms is less obvious. [...] It remains unclear to what extent the implementation is monitored, followed-up and if necessary adjusted. Nevertheless, this is a necessary condition for a successful implementation of the plan.' (a staff member of a school system)

The only imperative rule of the game concerning ESD is the introduction of new 'cross curricular final objectives' in secondary education in 2010. In Flanders, final objectives (cross curricular as well as subject specific) adopted by the Parliament determine which key competences pupils have to achieve through compulsory education. Since all Flemish schools have the obligation to prove their efforts regarding the realisation of these final objectives, this legislative measure was regarded an important incentive for the implementation of ESD in formal education. Sustainable development was given a prominent place in these revised cross curricular final objectives through which the Flemish Parliament aimed to create 'a sort of safety net for valuable and socially relevant content that is inadequately addressed within the subject specific final objectives' (Flemish government 2009c - our translation). The key competences with regard to sustainable development were described as follows:

'The pupils

- participate in environmental policy and environmental performance at school;

- recognise the interrelatedness of economic, social an ecological aspects of sustainability issues and the effects of technology and policymaking;

- try to use space, resources, goods, energy and transport in a sustainable way; 
- try to find sustainable solutions for the improvement of their local and global environment;

- show interest in and appreciation for nature, landscape and cultural inheritance;

- experience the value of nature and enjoy it.' (Flemish government 2009c, 18 our translation)

\section{Mobilisation, division and deployment of resources}

UNESCO and UNECE both emphasised that the provision of the necessary resources largely influences the success of the DESD.

'The IIS urges governments and other potential funding sources to assess the existing resources and needs related to ESD in their jurisdictions and to reallocate existing resources and find ways to create new resources. Even with linking existing programmes to ESD, a need for new resources exists. Additional human resources and funding will be necessary to augment current resources.' (UNESCO 2005, 24).

Pointing to these international statements, the need for sufficient human and financial resources has been stressed repeatedly throughout the Flemish policy process (Flemish government 2005a; VLOR and Minaraad 2007; Verheyen 2009; Flemish government 2009b; Flemish government 2010a). The conclusion that to date very little new resources have been provided brought about explicit criticism within the ESD consultation platform (Flemish government 2010a). Participants that responded to our survey, too, voiced such criticism:

'Governmental support and resources for ESD are very limited, in my opinion too limited. The activities and reports of the ESD consultation platform show great enthusiasm, a lot of creativity and devotion from the Environmental Education Unit [...] as well as other participating public services and NGOs. It is obvious that a more substantial funding and support by the Government would enhance Flemish ESD policy.' (a university professor)

As our document analysis showed (e.g. Flemish government 2010a) and the interviewee explained, since the Government of Flanders did not allocate resources specifically to ESD policy, the implementation of ESD in Flanders so far depended largely on the redistribution of funds within the existing budgets of several departments. Tangible policy measures were thus the result of the commitment of actors within public administration rather than the outcome of deliberate political decision making. Initially, the actions put forward in the Flemish ESD Implementation Plan were for the most part financed with funding for EE. Later on, however, other collaborating partners started to contribute, they too falling back on the reallocation of existing means.

When taking stock of the realisation of the ESD Implementation Plan and the Flemish Strategies on Sustainable Development, the consultation platform concluded that the lack of significant resources disabled the realisation of several actions such as an ESD project fund and process coaching for ESD organisations and professionals (Flemish government 2010a). On the other hand, the actors involved indicated that being on a budget also stimulated 
collaboration and creativity as a result of the search for co-funding and that it opened up a space for experimentation because of the absence of top-down steering and management.

'Restricted resources created the situation in which there were no indicators, evaluation tools, and expectancies embedded in hierarchic structures. This would have been the case if the minister would genuinely be interested in ESD and set targets that we have to reach. This could possibly have influenced the policy process negatively rather than positively because things get managed then and people feel obliged to do something. Whereas now, we are all in the same boat, with little support and funding from the Government. This fostered collaboration instead of competition. [...] Yet, now time has come to help the matter along with the necessary funding.' (a civil servant)

The situation with regard to the deployment and division of personnel was very similar (Flemish government 2005b) in that new recruitment for ESD failed to occur while the DESD brought about changes in the tasks and responsibilities of existing personnel (Flemish government 2010b). In the EE Unit, two policy advisors were deployed to coordinate the ESD consultation platform and to study and foster ESD as an important trend in EE policy and practice (Flemish government 2010a). In other policy areas (e.g. the Department of Education and Training, the Tourism Flanders Brussels Agency, the Flemish Department of Foreign Affairs, the Department of Culture, Youth, Sport and Media and the Agency for SocioCultural Work for Young People and Adults) staff members were not full-time seconded but spent time on the promotion, coordination and implementation of ESD in their policy area.

\section{Policy discourses and programmes}

With our analysis of policy discourses we both focus on the actors' views and narratives about sustainable development, education, and ESD and on the specific content of policy documents and measures (Arts et al. 2006).

Through cooperating with diverse actors for concrete realisations such as workshops or publications, the members of the ESD consultation platform experienced that ESD is a 'difficult' concept, a flag that covers a diverse cargo: it is applied in various and very different fields. Therefore, a task force was set up so as to create a common conception of ESD (Flemish government 2009b) resulting in the brochure 'ESD: Flag and Cargo' (2010c) that described ESD as

'[...] learning to think about and work towards a liveable world, now and in the future, for ourselves here and others elsewhere on the planet. The aim is therefore to equip individuals and groups with the skills they need to make conscious choices for such a liveable world' (Flemish government 2010c, 4-5).

In order to achieve these aims, according to the brochure, ESD has to pay attention to a number of key principles: transferring new knowledge, encouraging systems thinking, aiming at value development, taking into account emotional aspects and being actionoriented. The interviewed policy advisor argued how this brochure has influenced ESD practices in Flanders. It has been issued on 3.000 copies and diverse actors referred to it in 
their own publications, mission statements and educational materials. In our survey seven respondents indeed explained that this brochure influenced their understanding of ESD. Furthermore, in the answers to our question about how they conceptualised ESD elements regularly occurring were the assumption that ESD is a matter of information, awarenessraising, and participation that should contribute to a change in attitude, mind-set, and behaviour; that it should foster support for sustainability measures; that it should prepare people for their role in a sustainable world by developing the necessary competences; and that it should enable people to make proper choices.

'[ESD is] showing students the need for a transition, preparing them for the things to come, and letting them participate in this transition.' (a university college lecturer)

'[ESD is] the development of competences that contribute to making sustainable choices, taking into account the impact now and in the future, for ourselves and for others, here and elsewhere.' (a NGO staff member)

Whereas some respondents understood sustainable development as a balance between people, planet, and profit, others strongly contested this view.

'[Sustainable development is] the sustainable use of resources, thinking about the future (long term) while developing new processes in all areas, cradle to cradle, seeking balances between the economy and the environment...' (a civil servant)

'What should certainly be avoided, is taking for granted the image of a balance between people, planet, and profit. In contrast with assumptions from the managerial point of view, those three aspects are not of equal value. That is why I prefer the image [...] representing the economy (profit) as an embedded sphere within society (people) that is in its turn embedded in the environment (planet). This image is very useful to clarify what sustainable development is really about.' (a university college lecturer)

A related discussion that regularly arose in the policymaking process regarded the relation between EE and ESD (Flemish government 2005a; Minaraad 2007; Cherretté 2009). Most stakeholders considered EE as just one subset of ESD, alongside, for example, health-, peace-, citizenship-, development-, human rights education. This broad variety of educational efforts, it was argued by the strategic advisory councils for education and for environment, nature and energy policy, should contribute to ESD, which, then, serves as a 'compass' for all forms of education by interpreting various contents within the sustainable development framework (VLOR and Minaraad, 2007). On the other hand, it was emphasised that not the entirety of EE practice should be reoriented towards ESD. Basic nature education remains valuable. This view was also reflected in the brochure 'ESD: flag and cargo' and has been expressed by three respondents that participated in our survey. Furthermore, eleven respondents explained that the DESD has been a trigger for reflection on current (EE) practices. Three of them particularly mentioned their participation in the task force that wrote 'ESD: flag and cargo'. The interviewee, too, stressed that the DESD has brought about a time 
for reflection about day-to-day practices, not only about EE but also about education in general. This also fostered discussions about how to understand education.

\footnotetext{
'A $[\ldots]$ tension with regard to the conception of education, is the difference between those who think instrumentally, based on a strong sense of urgency, and plea for direct behavioural change as opposed to others who support a pedagogical, emancipatory perspective putting the learning process and personal development first rather than direct results.' (a civil servant)
}

Since 'green economy' was put forward by the UNECE Steering Committee for the DESD as an important topic, it was a core subject of discussion within the ESD consultation platform (Flemish government 2011; 2012b; 2012c). In a UNECE discussion paper, ESD and green economy - understood here as 'an economy where economic prosperity can go hand-inhand with ecological sustainability' (UNECE 2011, 3) - were considered to be 'two sides of the same coin' (Ibid. 2), that is, ESD was assumed to master the greening the economy from the bottom up 'because it has the ability to equip people with the values, competences, knowledge and skills that are necessary for them to put the green economy concept into practice'. Thus, the emphasis was on fostering 'green skills', raising awareness ('sustainable thinking'), and promoting sustainable consumption and production.

During the meeting of the ESD consultation platform in October 2012 (Flemish government 2012c) the participants were asked to report on their intentions with regard to 'green economy' as well as on how they view the role of the platform in this respect. As to the latter, the response was somewhat ambiguous. On the one hand, the platform was urged to take concrete initiatives (e.g. curricular reform) and mobilise relevant stakeholders (e.g. the Minister of Education and business partners). On the other hand however, several participants argued that the concept of green economy remains unclear and ambiguous and emphasised the need for further study, training, and information exchange as well as the importance of 'remaining critical', particularly with respect to how the notion of green economy is framed on the international level.

\section{Discussion: the interaction of Flemish ESD policymaking with broader societal developments}

We analysed Flemish ESD policymaking as to the actors involved, the resources that are mobilised, the rules of the game as well as the discourses regulating policy practice on ESD. In the remainder of this article, we discuss how this day-to-day policymaking process is inextricably intertwined with three overall developments in environmental and educational policymaking that influence ESD policy and practice: the increasing impact of ESD policy and discourse on EE, the framing of social and political problems as learning problems, and ecological modernisation. In this section, we address this interaction drawing on our empirical analysis and connecting it to the academic discussion on these developments. Next, in the conclusions, we critically synthesise the insights emerging from this analysis by bringing to the fore how these three developments contribute to a post-ecologist and post-political perspective on EE and ESD. 


\section{The influence of ESD policy and discourse on EE}

With the Brundtland Report the concept of 'sustainable development' was launched as a 'development that meets the needs of the present without compromising the ability of future generations to meet their own needs.' (WCED 1987, 43). Since then this notion increasingly influences EE (Tilbury 1995; Postma 2004). This evolution is in essence policy-driven (Jickling and Wals 2007; Nomura and Abe 2009) as it has been furthered by a succession of decisions made by international institutions. Agenda 21, the global action plan that arose from the United Nations Conference on Environment and Development (Earth Summit) in Rio de Janeiro in 1992 considered EE as an essential instrument for the realisation of a sustainable future and devoted a chapter on 'Promoting Education, Public Awareness and Training'. The UN Summit in Johannesburg in 2002 (Rio+10) endorsed the importance of education in the pursuit of sustainability and incited for the establishment of the UN Decade of ESD which, eventually, has been announced on December 20, 2002 by the UN General Assembly. Our case study indeed revealed how the growing influence of ESD policy and discourse did not only bring about a reallocation of resources (funds and personnel) from EE to ESD but also implied that policymaking within the EE unit was increasingly influenced by strategies that were put forward by international institutions.

Yet, the observation that ESD is becoming more and more established in EE does not imply that the relation between both concepts is clear for everybody. Several authors have argued that the distinction between EE and ESD remains insufficiently clarified and that a multitude of different perspectives exists simultaneously (Gadotti 2008; Mogensen and Schnack 2010; Reid and Scott 2006; Chapman 2007). The efforts made in Flanders so as to develop a shared understanding of ESD (cf. the brochure 'ESD: flag and cargo') can be seen as an attempt to clarify this notion that is perceived as a 'difficult concept' and to increase understanding as to how it relates to $\mathrm{EE}$ and other educational fields. The strategic advisory councils for environment, nature and energy policy and for education also engaged in such a discussion that resulted in an image of ESD as 'a compass' for all forms of education.

Furthermore, opinions concerning the desirability of ESD as a new leitmotiv for EE are also sharply divided. Whereas policymakers worldwide pay lip service to sustainable development and ESD enthusiastically, in research literature a persistent debate is going on between advocates and opponents of the concept of sustainable development in general as well as of the idea to replace EE by ESD. Critics consider sustainable development an ambiguous catch all term that conjoins profoundly contradictory meanings and, in its vagueness, succeeds in reconciling the most conflicting ideologies (e.g. Dobson 1996; Gunder 2006; Jickling and Wals 2007; Räthzel and Uzzell 2009). Sustainable development is thus the subject of a continuous, more or less explicit struggle over divergent interpretations which, critics argue, has been settled in favour of neoliberal economic thought and its concomitant political ideals which serve as an impediment for fundamental social change (Huckle 1999; Gunder 2006; Jickling and Wals 2007; Gadotti 2008). We observed how this struggle was also felt in Flemish ESD policymaking as it was reflected in the discussion about the conception of sustainability as a balance between people, planet, and profit.

Thus, since this problematic notion of sustainable development turned up in the context of EE, it brought about contestation as to the desirability to complement or replace EE 
with ESD. We found how diverse actors in Flanders emphasised the value of 'basic nature education' and stressed that not the entire EE sector should be reoriented towards ESD. In the scholarly debate, advocates of ESD consider it an indispensable contribution to the pursuit of sustainable development (e.g. McKeown and Hopkins 2007; Paden and Chhokar 2007; Bajaj and Chiu 2009; Hopkins 2009), while opponents regard this stance as an undue instrumental approach to education, reducing it to merely an instrument to promote a specific, predetermined kind of 'sustainable' behaviour (e.g. Jickling 1994; Sauvé 1999; Scott 2002; Jickling and Wals 2007; Breiting 2009; Östman 2010; Lundegård and Wickman 2012). They argue that this brings about homogenising effects - all the more problematic because of the ambiguity that characterises the notion of sustainability - and reduces the space for autonomous decision-making. Therefore, they emphasise that EE and ESD demand a 'pluralistic' approach to education, one that acknowledges, stimulates, and engages a variety of values, interests, and knowledge claims. Although the plea for such a pluralistic approach is broadly supported by EE and ESD scholars, at the same time the concern is raised that pluralistic educational practices might be inadequate to address urgent sustainability problems (e.g. Læssøe 2007; Wals 2010; Kopnina 2012). As the policy advisor we have interviewed indicated, a similar discussion between 'those who think instrumentally' and 'others who support a pedagogical, emancipatory perspective' emerged in Flanders as well.

Furthermore, the scholarly debate about EE and ESD elaborately addresses gaps between discourse and practice. Some authors argue that, because of the focus on ESD, the merits of environmental education's long tradition, that is, a body of literature and several (international) Declarations, is overlooked so that valuable ideas and experiences fall into oblivion and time is wasted on the 're-invention of the wheel' (Palmer 1998; Berryman 1999; Sauvé 1999; Chapman 2007; Gadotti 2008). ESD advocates acknowledge these merits, yet they raise objections to dominant practices of environmental education that are failing to realise the ambitious principles and purposes put forward in the discourse on it (Smyth 1999; González-Gaudiano 1999; Gough and Scott 1999). The DESD, it is argued, then provides the opportunity for a 'fresh start' (Huckle 1999). Opponents, however, doubt that the discourse on ESD will ensure 'desirable' practices. A similar gap between discourse and practice can emerge here as well (Sauvé 1999; Sauvé and Berryman 2005; Selby 2006; Mogensen and Schnack 2010). In Flanders, the interviewed policy advisor as well as several respondents to our survey indicated that the DESD served as 'a trigger for reflection' on current (EE) practices.

\section{The framing of social and political problems as learning problems}

An undeniable development within overall educational policy - but also educational theory and practice - is the tendency to frame social and political problems as 'learning problems' (Biesta 2004; Simons and Masschelein 2006; 2009). During the twentieth century the role of education within society changed as national governments started to think of themselves as being responsible for governing the relation between education and society (Simons and Masschelein 2006). This relation has been conceived in different ways. For instance, education has been understood as a prerequisite in the pursuit of social transformation (e.g. reducing social inequality) but also as a necessary instrument for the conservation of 
particular social and cultural values and, thus, to secure the stability of society. Despite such ideological differences, Simons and Masschelein highlight the shared horizon for this governmental concern with the role of education in society: the assumption that governments have to intervene in education in view of social (and related cultural or economic) concerns. In other words, learning emerges as a solution for numerous problems and learning policy and experts in education are deployed to resolve social problems. Individual learners should acquire the 'proper' knowledge, insights, skills, and attitudes. They have to 'learn' to adapt their behaviour to what is considered desirable and make themselves competent to deal with the given challenges. This tendency is part of a broader process of individualisation in contemporary society where the responsibility for social problems is increasingly reserved for individual people (Finger and Asùn 2001). Drawing on the insights of Michel Foucault, Simons and Masschelein $(2006,414)$ elaborate how the 'governmentalisation of learning' is closely linked to the individualisation and de-socialisation of problems as in the current governmental regime individuals are addressed as 'subjects that are situated in an environment which [they] have to adapt proactively and creatively in order to satisfy [their] needs - that is, a regime in which [they] are (interpellated to be) entrepreneurial selves'. Learning, thus, is increasingly understood as a condition for individual autonomy and people are addressed as being responsible for (regulating) their own learning.

This tendency to translate 'societal problems' into 'educational solutions' (Simons and Masschelein 2006, 395) pre-eminently applies to ecological issues and sustainable development. Ever since the relationship between people and their natural environment has been conceived as problematic, appeals have been made to education (Postma 2004). Since the beginning of the twentieth century there is a field of educational theory and practice developing from nature education over conservation education and environmental education toward education for sustainable development (Tilbury 1995; Palmer 1998; Postma 2004). Within this historical development, at least one thing remained constant: education has predominantly been conceived as an instrument to tackle the evolving social and political challenges concerning the environment. In confrontation with changing ecological problems such as urban children's increased alienation of nature, problems of nature conservation, the environmental crisis and issues of (under)development educational policy and reform are designed to change people's behaviour, attitude, and mentality in a particular, preconceived way.

In our case study ecological and sustainability issues predominantly emerged as matters of individual learning and the aims of EE and ESD were almost exclusively defined in terms of individual dispositions. This was strongly reflected in the only imperative rule of the game on ESD in Flanders, that is, the revised final objectives that translated sustainability in a set of 'key competences' individual pupils should achieve. Furthermore, the way ESD was defined in 'ESD: flag and cargo' as a process of 'equipping individuals and groups with the necessary skills to contribute to a liveable world', as well as the key principles put forward in this brochure and the conceptualisation of the relation between ESD and green economy also show how the social and political challenge of sustainability is easily translated in 'educational solutions' (e.g. the transfer of knowledge and values, green skills, competences such as systems thinking). The answers to our postal survey emphasising e.g. awarenessraising, behavioural adjustment, and the need to prepare people for their role in a sustainable 
world by developing the necessary competences revealed the prevailing of a similar interpretation of ESD. An ecologically sound and sustainable society emerges thus as a challenge that can be met by applying the proper learning strategies and, thus, education becomes first and foremost a matter of socialisation, that is, the acquisition of particular knowledge, skills, competences, or dispositions. EE and ESD are reduced to instruments to foster the values and principles of sustainable development, to promote corresponding behavioural changes, and to qualify people for the role of active participants that contribute to the democratic realisation of sustainable development (Ferreira 2009; Van Poeck and Vandenabeele 2012). As we already showed above, this tendency to frame sustainability as a learning problem is also addressed in the debate concerning the influence of ESD policy and discourse on EE as such an 'instrumental' approach to education is criticised by scholars as well as policy actors. A particular subject of discussion within the Flemish policy process was the taken-for-granted connection between a competence oriented understanding of ESD and the pursuit of a green economy.

\section{Ecological modernisation}

The framing of sustainable development as a learning problem is reinforced by a third development we want to address: the discourse of 'ecological modernisation' as the new dominant way of conceptualising environmental problems in the Western world that has emerged since the late 1970s as a result of a particular interplay between governments, environmental movements, and key expert organisations (Hajer 1995). Here, too, the Brundtland Report is considered a milestone for the emergence of this discursive shift within different industrialised countries as well as in international organisations such as the UN, the OECD, and the European Union (Hajer 1995; Mol and Spaargaren 2000). In line with Hajer $(1995,44)$ we understand 'discourse' as a 'specific ensemble of ideas, concepts, and categorisations that are produced, reproduced, and transformed in a particular set of practices and through which meaning is given to physical and social realities'. Acknowledging the consideration that (environmental) discourse is thus inevitably place and time specific as well as the need to differentiate between different sorts of ecological modernisation (Hajer 1995; Christoff 1996; Mol and Spaargaren 2000), we nevertheless want to depict the overall features of this discourse as these influence ESD policymaking in Flanders today.

Although within the discourse of ecological modernisation it is acknowledged that 'structural design faults' in the core institutions of modern society - i.e. the industrialised production system, the capitalist organisation of the economy and the centralised state - cause severe environmental destruction (Mol and Spaargaren 2000) it is all the same assumed that the existing political, economic, and social institutions can internalise the care for the environment (Hajer 1995). Hence, a fundamental transformation of these societal structures does not appear here as a prerequisite for tackling this crisis. As such, ecological modernisation challenges the radical environmentalist critique of the 1970s that argued for a fundamental reorganisation of those institutions that are involved in the modern organisation of production and consumption. A key assumption is, thus, the possibility of reconciling economic growth, technological development and the solution of ecological problems. Within this discourse, the environmental challenge is regarded a management problem as well as a 
'positive-sum-game': 'there would be no fundamental obstructions to an environmentally sound organisation of society, if only every individual, firm, or country, would participate' (Hajer 1995, 26). In Flanders, the influence of an ecological modernisation perspective can be found in the discourse about a green economy 'where economic prosperity can go hand-inhand with ecological sustainability' as well as in the conception of sustainability as a balance between ecological, social, and economic concerns. We also showed, however, that both discourses were the subject of discussion among the actors involved.

Hajer (1995) emphasises that although the political scientists who introduced the concept of ecological modernisation (Joseph Huber and Martin Jänicke) allocated a central role for technological innovation and economic development, the conceptual change actually stretches to many other domains (see also Mol and Spaargaren 2000) such as the techniques of environmental policymaking, the role of science and scientists, micro-economic and macro-economic strategies, the legislative discourse and, finally, participatory practices. As to the last, ecological modernisation brought about a reconsideration of participation seeking to bring to an end the former sharp antagonistic debates between the state and the environmental movement by acknowledging new actors and creating new practices (e.g. active funding of NGOs, round table discussions). Læssøe (2007; 2010), too, highlights that ecological modernisation did not only put forward 'participation' as a new buzzword but also brought about a reconsideration, i.e. a narrowing of participatory practices. His analysis of citizen participation in environmental issues in Denmark reveals an orientation towards consensus and the marginalisation of any conflicts or contestation concerning values, political ideology, and the ever-present tension between private and collective interests. In our case study, such a reconsideration of participatory practices was reflected in the role of the ESD consultation platform (i.e. contributing to the implementation of policy), the way it was composed of a variety of actors collaborating as a coalition of ESD advocates, and the persistent criticism about the lack of involvement of 'all relevant stakeholders'. Yet, here too, contestation emerged as well, particularly as to the desirability to build alliances (and, thus, consensus) with partners from business circles.

Although this focus on consensus building is clearly a feature that sustainable development and ecological modernisation have in common, Langhelle (2000) highlights that both concepts should not be conflated. He argues that sustainable development attempts to address a number of issues about which ecological modernisation has nothing to say: global environmental problems, distributional problems, social justice (intragenerational as well as intergenerational), nature's carrying capacity, ecological limits, and global ecological interdependence. As such, conceptualising 'education for ecological modernisation' might be very helpful to nurture the debate about EE and ESD that we addressed above. Theoretical as well as empirical research on how the discourse of ecological modernisation affects EE and ESD policy and practice could inform, for example, the discussions about whether or not ESD contributes to neoliberal globalisation and about the gap between discourse and practice of EE and ESD. It would move beyond the scope of the present article to go into this elaborately. Nevertheless, our case study revealed that although - as indicated above - the discourse of ecological modernisation influences Flemish ESD policymaking in some respects, the implementation of the DESD in Flanders cannot be reduced to the introduction or encouragements of education for ecological modernisation. We cannot maintain that all the 
aforementioned issues remain unaddressed. For instance, the emphasis put on the value of basic nature education - although the policy documents and respondents remain rather vague and superficial in this respect - reflects some kind of concern for ecological limits and the planet's carrying capacity. Furthermore, the issues of inter- and intragenerational justice is embedded in the brochure 'ESD: Flag and Cargo' that appeals for 'a liveable world, now and in the future, for ourselves here and others elsewhere on the planet'.

\section{Conclusions}

Our analysis of the Flemish policy practice shows how the increasing influence of ESD policy and discourse on EE, the framing of sustainability as a learning problem, and ecological modernisation gave shape to the boundaries of a particular governmental regime. Drawing on Foucault's 'governmentality' perspective, Ferreira (2009: 612) argues that within such a regime 'a range of semi-normative prescriptions [...] work to include, exclude and govern what it is acceptable (possible) to think and what it is acceptable (possible) to do' (Ferreira 2009,612 ). The policy-driven emphasis on ESD, for instance, tends to foster a consensual understanding of the ambiguous concept of sustainable development in favour of neoliberal economic and political thought thereby pushing into the background arguments for fundamental social change. The framing of sustainability as a learning problem reinforces individualisation and de-politicisation whereby the responsibility for unsustainability is increasingly attributed to individuals. The discourse of ecological modernisation also marginalises appeals for fundamental transformations of societal institutions and reduces the space for conflict and contestation. Furthermore, its consensus orientation conceals genuine political issues regarding e.g. distributional problems, social justice, or the question how to deal with non-negotiable ecological limits in an ecologically interdependent, globalised world. As such, that which is acceptable and possible to think and to do corresponds well both with what Blühdorn $(2011 ; 2013)$ labels 'post-ecologism' and with the 'post-political' condition described by, among others, Swyngedouw (2007), Rancière (1999), and Mouffe (2005). Since the late 1980s the post-ecologist turn that emerged in capitalist consumer democracies pushed into the background the ecologist critique of 'the pathologies of modernity' as well as the desire for and the vision of a fundamentally different society in the economic, ecological, political, social, and cultural sphere (Blühdorn 2013: 18-19). Within this context, the ecological issue has been thoroughly depoliticised (Blühdorn 2011). In this post-political era, the existing order is no longer disrupted and struggle and dissensus indispensable ingredients in framing genuine political questions about ecological issues - are avoided.

The analysis we presented above shows how the three developments we addressed and the way they trickle-down in the international and Flemish ESD policy contribute to a governmental regime with post-ecologist and post-political boundaries. Nevertheless, our case study also shows that this regime does not completely determine ESD policymaking in Flanders. We observed, for instance, that whereas stakeholders' role in the consultation platform has been set rather formalistically (representation, consultation, and implementation of the DESD) participants themselves described it in terms of a valuable dialogue, where differences could sometimes be articulated and could work as a trigger for reflection on 
existing educational practices and policy. The prevailing (competence-oriented) instrumental conception of education has been the subject of discussion as well as, for example, the connection between ESD and green economy and the need to build alliances with partners from business circles. Our analysis of the policymaking process with regard to ESD in Flanders within the context of those broader social and political developments allowed us to understand how policy settings bring about powers that legitimise and maintain as well as counteract the bounds of a particular governmental regime (Duyvendak and Uitermark 2005, Ferreira 2009).

Obviously, more empirical research is required so as to achieve a more comprehensive understanding of the DESD and the actual policy translations and implementation processes it has brought about. The need for further research can be situated at different levels of analysis: overall social and political developments (the three we addressed above can be further analysed and other significant tendencies might be identified), international policymaking, national and subnational policymaking (in diverse geographical contexts), and practices in the field. Of particular importance so as to achieve a deeper understanding of the DESD are empirical case studies focusing on the interaction between social and political developments, policymaking, and educational practices . The present case study on ESD policymaking in Flanders is part of a broader doctoral research project in which we also studied very different educational practices: the Transition Towns movement, the project 'Environmental Performance at School' ('Milieuzorg Op School'), an environmental education centre, a Community Supported Agriculture initiative, a regional centre for action, culture, and youth, a transition arena for a climate neutral city, and an organisation that offers workshops to promote ecological behaviour change (Van Poeck 2013). These multiple case studies, too, show how social and political developments and the (international and Flemish) ESD policymaking contributes to the establishment of a particular regime which defines the contours of what is 'sayable', 'seeable', 'thinkable', and 'possible' (Simons and Masschelein, 2010: 512) in educational practices. It co-constructs what becomes (im)possible in concrete practices as well as how we can (or should) think and speak about these practices and here, too, this particular regime align well with the post-ecologist and post-political context described above. Our analysis revealed that the increased focus on ESD also influences the examined EE practices in that the consensual catch-all term 'sustainable development' reduces the space for contestation and controversy within these practices. Furthermore, we repeatedly observed how the prevailing discourse of ecological modernisation and its emphasis on 'collaboration' between 'allies' and on 'managing' ecological problems encourages practitioners to see the issues at stake and to think and speak about them in a postecologist and post-political way and to act accordingly. Finally, we found that the framing of sustainable development as a learning problem fostered an emphasis on socialisation and qualification within the examined EE practices. Yet, here too, the practices we studied were not fully determined by this regime and, at particular moments, something different emerged. For instance, we observed educators explicitly questioning the consensual account of sustainability implied in the Triple-P perspective (the balance between People, Planet, and Profit). We witnessed practices where complex and contested sustainability issues and the often antagonistic values, interests, and knowledge claims inherent in them were thoroughly explored and discussed. At such moments, educational practices did create a space for the 
enactment of controversy around the existing order, for the framing of political questions concerning how to understand and achieve sustainability, and for developing diverse visions about a fundamentally different society.

Masschelein and Simons (2003) emphasise that - although it might be tempting - a regime such as the one we described cannot be interpreted as a 'system' that can be changed (or, at least, that we can try to change) according to plan. Rather, it generates effects by appealing to people (i.c. ESD and EE policymakers and practitioners but also participants) for a particular way of seeing, speaking, thinking, and acting (i.c. in relation to sustainability issues and educational practices). With our research, we aim to describe and, thus, to show EE/ESD policy and practices sometimes legitimise and maintain but at particular moments also counteract the bounds of this regime. By bringing this forward in our descriptions we want to invite and inspire the reader to be attentive to different ways of seeing, speaking, thinking, and acting. Such inquiries can contribute to what Ferreira (2009) calls 'unsettling the taken-for-granted' in EE and ESD, illuminating how certain orthodoxies have become 'normal' and 'obvious' all the same, how these orthodoxies assumes the possibility of infringement, and subversion (Duyvendak and Uitermark 2005; Ferreira 2009).

\section{Acknowledgement}

The authors thank the three anonymous reviewers of this paper for their valuable comments and very helpful suggestions.

\section{References}

Arts, B., van Tatenhove, J. P. M., and P. Leroy. 2000. Policy arrangements. In: Political Modernisation and the Environment. The Renewal of Environmental Policy Arrangements, eds. J.P.M.van Tatenhove, B. Arts, and P. Leroy, 53-69. Dordrecht: Kluwer Academic Publishers.

Arts, B., Leroy, P., and J.P.M. van Tatenhove. 2006. Political Modernisation and Policy Arrangements: A Framework for Understanding Environmental Policy Change. Public Organization Review 6, no. 2: 93-106.

Bajaj, M. and B. Chiu. 2009. Education for Sustainable Development as Peace Education. Peace \& Change 34, no. 4: 441-5.

Belgian Constitution, amendments of April 25, 2007, art.7bis, published in the Bulletin of Acts on April 26, 2007.

Berryman, T. 1999. Relieving modern day Atlas of an illusory burden: abandoning the hypermodern fantasy of an education to manage the globe, Canadian Journal of Environmental Education 4, no. 1: 50-69.

Biesta, G. 2004. Democracy - A problem for education or an educational problem? In Five Professors on Education and Democracy, ed. T. Englund, 89-109. Örebro: Örebro University. 
Blühdorn, I. 2011. The Politics of Unsustainability: COP15, Post-Ecologism, and the Ecological Paradox, Organization and Environment 24, no. 1: 34-53.

Blühdorn, I. 2013. The governance of unsustainability: ecology and democracy after the postdemocratic turn, Environmental Politics 22, no. 1: 16-36.

Breiting, S. 2009. Issues for environmental education and ESD research development: Looking ahead from WEEC 2007 in Durban. Environmental Education Research 15, no. 2: 199-207.

Chapman, D. 2007. Environmental education/education for sustainability: What is the difference? [online] New Zealand Association for Environmental Education. Available from: http://www.nzaee.org.nz/index.asp?pageID=2145880172 [Accessed 26 March 2010].

Cherretté, M. 2009. Policy plan and view on environmental education (2009-2014) [Visie - en beleidsnota Natuur - en Milieueducatie (2009-2014)], 1-9. Brussels: Flemish government.

Christoff, p. 1996. Ecological Modernisation, Ecological Modernities. Environmental Politics 5, no.3: 476-500.

Dobson, A. 1996. Environmental sustainabilities: an analysis and a typology, Environmental Politics 5, no. 3: 401-28.

Duyvendak, J.W. and J. Uitermark. 2005. De opbouwwerker als architect van de publieke sfeer. Beleid \& Maatschappij 32: 76-89.

Ferreira, J. 2009. Unsettling orthodoxies: education for the environment/for sustainability. Environmental Education Research 15, no. 5: 607-20

Finger, M. and J. M. Asún. 2001. Adult Education at the Crossroads. Learning Our Way Out. London and New York: Zed Books.

Flemish government. 2005a. Report ESD consultation platform, June 9, 2005 [Verslag EDOoverlegplatform 9 juni 2005]. Brussels: Flemish government.

Flemish government. 2005b. Report ESD consultation platform, November 17, 2005 [Verslag EDO-overlegplatform 17 november 2005]. Brussels: Flemish government.

Flemish government. 2008a. Report ESD consultation platform, April 17, 2008 [Verslag EDO-overlegplatform 17 april 2008]. Brussels: Flemish government.

Flemish government. 2008b. Report ESD consultation platform, October 9, 2008 [Verslag EDO-overlegplatform 9 oktober 2008]. Brussels: Flemish government.

Flemish government. 2009a. Learning for a viable future. Flemish implementation plan for $E S D$ [Leren voor een leefbare toekomst. Vlaams implementatieplan voor Educatie voor Duurzame Ontwikkeling]. Brussels: Flemish government.

Flemish government. 2009b. Report ESD consultation platform, April 20, 2009 [Verslag EDO-overlegplatform 20 april 2009]. Brussels: Flemish government. 
Flemish government. 2009c. New cross-curricular final objectives for secundary education [VOET@2010. Nieuwe vakoverschrijdende eindtermen voor het secundair onderwijs] Brussels: Flemish government.

Flemish government. 2010a. Report ESD consultation platform, April 22, 2010 [Verslag EDO-overlegplatform 22 april 2010]. Brussels: Flemish government.

Flemish government. 2010b. Report on the state of affairs concerning the implementation of the UNECE Strategy for education for sustainable development [Rapport over de stand van zaken m.b.t. de implementatie van de UNECE Strategie voor Educatie voor Duurzame Ontwikkeling]. Brussels: Flemish government.

Flemish government. 2010c. Education for Sustainable Development: flag and cargo. Brussels: Flemish government.

Flemish government. 2011. Report ESD consultation platform, June 22, 2011 [Verslag EDOoverlegplatform 22 juni 2011]. Brussels: Flemish government.

Flemish government. 2012a. Flemish Regional Indicators 2012 [VRIND 2012 Vlaamse Regionale Indicatoren]. Brussels: Flemish government.

Flemish government. 2012b. Report ESD consultation platform, April 16, 2012 [Verslag EDO-overlegplatform 16 april 2012]. Brussels: Flemish government.

Flemish government. 2012c. Report ESD consultation platform, October 2, 2012 [Verslag EDO-overlegplatform 2 oktober 2012]. Brussels: Flemish government.

Gadotti, M. 2008. Education for Sustainability: A Critical Contribution to the Decade of Education for Sustainable Development. Green Theory \& Praxis: The Journal of Ecopedagogy 4, no. 1: $15-64$.

González-Gaudiano, É. 1999. Environmental Education and Sustainable Consumption: The Case of Mexico. Canadian Journal of Environmental Education 4, no. 1: 176-92.

Gough, S. and W. Scott. 1999. Education and Training for Sustainable Tourism: Problems, Possibilities and Cautious First Steps. Canadian Journal of Environmental Education 4, no. 1: 193212.

Gunder, M. 2006. Sustainability. planning's saving grace or road to perdition? Journal of Planning Education and Research 26, no. 2: 208-21.

Hajer, M. 1995. The politics of environmental discourse. Ecological modernization and the policy process. New York: Oxford University Press.

Hopkins, C. 2009. Enough, for all, forever: the quest for a more sustainable future. Education Canada 49, no. 4: 42-6.

Huckle, J. 1999. Locating Environmental Education Between Modern Capitalism and Postmodern Socialism: A Reply to Lucie Sauvé. Canadian Journal of Environmental Education 4, no. 1: $36-45$. 
Huckle, J. 2009. Consulting the UK ESD community on an ESD indicator to recommend to Government: an insight into the micro-politics of ESD, Environmental Education Research 15, no.1: $1-15$.

Jickling, B. 1994. Why I don't want my children to be educated for sustainable development: sustainable belief. Trumpeter 11, no. 3: 2-8.

Jickling, B. and A.E.J. Wals. 2007. Globalization and environmental education: looking beyond sustainable development. Journal of Curriculum Studies 40, no. 1: 1-21.

Kopnina, H. 2012. Education for sustainable development (ESD): the turnaway from 'environment' in environmental education? Environmental Education Research 18, no. 5: 699-717.

Langhelle, O. 2000. Why ecological modernisation and sustainable development should not be conflated. Journal of Environmental Policy and Planning 2, no.4: 303-22.

Læssøe, J. 2007. Participation and sustainable development: The post-ecologist transformation of citizen involvement in Denmark. Environmental Politics 16, no. 2: 231-50.

Læssøe, J. 2010. Education for sustainable development, participation and socio-cultural change. Environmental Education Research 16, no. 2: 39-57.

Leterme, Y. 2006. Backing frontiers together. Flemish strategy for sustainable development. [Samen grenzen ver-leggen. Vlaamse strategie duurzame ontwikkeling]. Brussels: Flemish Government.

Lundegård, I. and P.O Wickman. 2012. It takes two to tango: studying how students constitute political subjects in discourses on sustainable development, Environmental Education Research 18, no.2: $153-69$.

Masschelein, J. and M. Simons. 2003. Globale immuniteit. Een kleine cartografie van de Europese ruimte voor onderwijs. Leuven: Acco.

McKeown, R. and C. Hopkins. 2007. Moving Beyond the EE and ESD Disciplinary Debate in Formal Education. Journal of Education for Sustainable Development 1, no. 1: 17-26.

Minaraad, 2007. Advice of March 22, 2007 concerning the implementation of ESD in environmental education policy [Advies van 22 maart 2007 over de organisatorische en beleidsmatige inschakeling en afstemming van natuur- en milieueducatie in de beleidsontwikkelingen rond EDO]. Brussels: Minaraad.

Minaraad, 2008. Advice of April 8, 2008 concerning the draft Flemish Implementation Plan on ESD [Advies van 8 april 2008 over het ontwerp van Vlaams implementatieplan voor Educatie voor Duurzame Ontwikkeling]. Brussels: Minaraad.

Mogensen, F. and K. Schnack. 2010. The action competence approach and the 'new' discourses of education for sustainable development, competence and quality criteria. Environmental Education Research 16, no. 2: 59-74. 
Mol A.P.J. and G. Spaargaren. 2000. Ecological Modernisation Theory in Debate: A Review. Environmental Politics 9, no. 1:17-49.

Mouffe, C. 2005. On the political. London: Routledge.

Nomura, K. and O. Abe. 2009. The education for sustainable development movement in Japan: a political perspective. Environmental Education Research. 15, no. 4: 483-96.

Östman, L. (2010). Education for sustainable development and normativity: a transactional analysis of moral meaning-making and companion meanings in classroom communication. Environmental Education Research 16, no. 1: 75-93.

Paden, M. and K.B. Chhokar. 2007. Exploring Research Priorities for the DESD. Journal of Education for Sustainable Development 1, no.1: 73-5.

Palmer, J. A. 1998. Environmental Education in the 21st Century: Theory, Practice, Progress and Promise. London and New York: Routledge.

Patton, M.Q. 2002. Qualitative Research \& Evaluation Methods. Thousand Oaks/London/New Delhi: Sage Publications.

Peeters, K. 2009a. Policy document General Government Policy 2009-2004 [Beleidsnota Algemeen Regeringsbeleid 2009-2014]. Brussels: Flemish government.

Peeters, K. 2009b. Policy document 2009-2014 Foreign policy, International enterprise and Development cooperation [Beleidsnota 2009-2014 Buitenlands beleid, Internationaal ondernemen en ontwikkelingssamenwerking]. Brussels: Flemish government.

Peeters, K. 2010. Backing frontiers together. Flemish strategy for sustainable development. [Samen grenzen ver-leggen. Vlaamse strategie duurzame ontwikkeling]. Brussels: Flemish Government.

Postma, D. W. 2004. Because we are human. A philosophical inquiry into discourses of environmental education from the perspective of sustainable development and man's caring responsibility, PhD diss., Katholieke Universiteit Leuven / Radboud Universiteit Nijmegen.

Rancière, J. 1999. Dis-agreement. Politics and philosophy. Minneapolis, MN: University of Minnesota Press.

Räthzel, N., and D. Uzzell. 2009. Transformative environmental education: A collective rehearsal for reality. Environmental Education Research 15, no. 3: 263-77.

Reid, A. and W. Scott, W. 2006. Researching education and the environment: retrospect and prospect. Environmental Education Research 12, no. 2/3, 571-87.

Sauvé, L. 1999. Environmental Education Between Modernity an Postmodernity: Searching for an Integrating Educational Framework. Canadian Journal of Environmental Education 4, no. 1: 935. 
Sauvé, L. and T. Berryman. 2005. Challenging a "Closing Circle": Alternative Research Agendas for the ESD Decade. Applied Environmental Education and Communication 4, no. 3: 229-32.

Schauvliege, J. 2009. Policy document Environment and Nature 2009-2014 [Beleidsnota Leefmilieu en Natuur 2009-2014]. Brussels: Flemish government.

Scott, W. 2002. Education and Sustainable Development: challenges, responsibilities, and frames of mind. The Trumpeter 18, no. 1: 1-12.

Selby, D. 2006. The Firm and Shaky Ground of Education for Sustainable Development. Journal of Geography in Higher Education 30, no. 2: 351-65.

Simons, M. and J. Masschelein. 2006. The Learning Society and Governmentality: An introduction. Educational Philosophy and Theory 38, no. 4: 417-30.

Simons, M. and J. Masschelein. 2009. The Public and Its University: beyond learning for civic employability. European Educational Research Journal 8, no. 2: 204-17.

Simons, M. and J. Masschelein. 2010. Hatred of Democracy ... and of the Public Role of Education? Introduction to the Special Issue on Jacques Rancière. Educational Philosophy and Theory 42, no. 5-6: 509-22.

Smet, P. 2009. Policy document 2009-2014 Education: Backing frontiers together for every talent [Beleidsnota 2009-2014 Onderwijs: Samen grenzen verleggen voor elk talent]. Brussels: Flemish government.

Smyth, J. 1999. Is there a Future for Education Consistent with Agenda 21? Canadian Journal of Environmental Education 4, no. 1: 69-83.

Swyngedouw, E. 2007. Impossible 'sustainability' and the post-political condition. In The Sustainable Development Paradox, eds. R. Krueger and D. Gibbs, 13-40. New York: Guilford Press

Tilbury, D. 1995. Environmental Education for Sustainability: defining the new focus of environmental education in the 1990s. Environmental Education Research 1, no. 2: 195-212.

United Nations Conference on Environment and Development (UNCED). 1992. Agenda 21, The United Nations Programme of Action from Rio. New York, UN.

United Nations Economic Commission for Europe (UNECE). 2005. UNECE Strategy for Education for Sustainable Development adopted at the High-level meeting of Environment and Education Ministries (Vilnius, 17-18 March 2005). New York, UN.

United Nations Economic Commission for Europe (UNECE). 2011. Discussion paper on the role of education for sustainable development in shifting to a green economy. New York, UN.

United Nations Organization for Education, Science and Culture (UNESCO). 2005. United Nations Decade of Education for Sustainable Development (2005-2014): International Implementation Scheme. Paris, UNESCO. 
Van Poeck, K. and J. Vandenabeele. 2012. Learning from sustainable development: education in the light of public issues. Environmental Education Research 18, no. 4: 541-52.

Van Poeck, K. 2013. Education as a response to sustainability issues. Practices of environmental education in the context of the United Nations Decade of education for sustainable development. $\mathrm{PhD}$ diss., Katholieke Universiteit Leuven.

VLOR and Minaraad. 2007. Advice of March 22, 2007 concerning education for sustainable development in compulsory education [Advies van 22 maart 2007 over educatie voor duurzame ontwikkeling in het leerplichtonderwijs]. Brussels: VLOR and Minaraad.

Verheyen, R. 2009. Education as a driving force for sustainable development in Flanders. Memorandum of the ESD consultation platform on the occasion of the elections for the Flemish Parliament in 2009 [Educatie als motor voor duurzame ontwikkeling in Vlaanderen. Memorandum van het EDO-overlegplatform naar aanleiding van de Vlaamse verkiezingen 2009].

Wals, A.E.J. 2010. Between knowing what is right and knowing that it is wrong to tell others what is right: on relativism, uncertainty and democracy in environmental and sustainability education. Environmental Education Research 16, no. 1: 143-51.

World Commission on Environment and Development (WCED). 1987. Our Common Future. Oxford: Oxford University Press. 